\title{
Preliminary Phytochemical Screening of Methanolic Extract Of Clerodendron infortunatum
}

\author{
Dr.Rimjhim Sheel ${ }^{1}$, Kumari Nisha ${ }^{2}$ and Prof. Jainendra Kumar ${ }^{3}$ \\ ${ }^{1}$ Associate Professor, Department of Botany, Ganga Devi Mahila College, Kankarbagh, Patna. \\ ${ }^{2.3}$ Department of Botany and Biotechnology, College of Commerce, Patna.
}

\begin{abstract}
Plants of genus Clerodendron belongs to family Verbenaceae and have been widely employed for controlling the various disease. Objective of the present study was to do preliminary phytochemical screening of Methanolic Extract of leaves of Clerodendron infortunatum. Qualitative phytochemical analysis of this plant confirms the presence of various phytochemicals like sterols, terpenoids, alkaloids, carbohydrates, tannins, and glycosides in its methanolic extract. Whereas flavonoids, phenols and saponins were found to be absent. This preliminary study draws attention to the need for further studies of the active secondary metabolites identified in the reported species for the treatment of many diseases also to understand their mode of action in controlling various dreadful diseases.
\end{abstract}

Keywords-Phytochemical, Clerodendron infortunatum, Methanolic Extract, Secondary metabolites.

\section{Introduction:}

Clerodendron infortunatum is a common shrub of $2-4 \mathrm{ft}$ height of the family Verbeaceae. It is found along road side in North India and elsewhere, and flowers during February- May (Haines,1925), identified by Linnaeus in 1753. In Ayurveda it is known by the Sanskrit names "Bharhi", "Bhrigubhava", "Padma", "Fanji" , and "Brahman yastika" (Shasthri,1977). In Kerela, as "Peruvelum," and in Hindi as "Bhant" or "Bharangi". More than 500 species of the genus Clerodendron are identified till now. Phyto-medical importance of various species of Clerodendron genus has been reported in various indigenous systems of medicines. This genus is being used specifically in Indian, Chinese, Thai, Korean, Japanese systems of medicine for the treatment of various diseases such as syphilis, typhoid, cancer, jaundice and hypertension. As phytochemicals or the secondary metabolites, play an important role in the biological activities hence, the present study is carried out for preliminary screening of phytochemical components of Methanolic extract of Clerodendron infortunatum .

Plants contain many active compounds such as alkaloids, steroids, tannins, glycosides, volatile oils, fixed oils, resins, phenols flavonoids etc,which are deposited in their specific parts such as leaves, flowers, bark, seeds, fruits, root, etc. The beneficial medicinal effects of plant materials typically result from the combination of these secondary products (Tonthubthimthong et al., 2001). In 1985 Farnsworth et al., identified 119 secondary plant metabolites which were used as drugs. Phytochemicals are known to possess antioxidant (Wong et al., 2009), antibacterial (Nair et al., 2005), antifungal (Khan and Wassilew, 1987), antidiabetic (Singh and Gupta, 2007; Kumar et al., 2008a), anti-inflammatory (Kumar et al., 2008b), radio-protective activity (Jagetia et al., 2005) etc and due to these properties they are largely used for medicinal purpose. Therefore, qualitative phytochemical screening of some medicinal plants are necessary and the present study is designed to evaluate the bioactive chemical constituents of Clerodendron infortunatum commonly used as medicine in India.

\section{Material and Methods:}

Collection of plant material and extraction:

Abundant population of the plant (Clerodendron infortunatum ) is present near nahar chowk, off West Bailey Road, Danapur catt. Samples were collected from the side of the canal, where abundant population of the plant (Clerodendron infortunatum ) is present. Leaves of the collected plants were separated, washed carefully with tap water, rinsed with distilled water, air dried for 1 hour, and shade dried. They were ground in to powder (coarsely) and stored at room temperature. The extract of the samples were prepared by soaking $100 \mathrm{gm}$ of dried powder in $200 \mathrm{ml}$ of methanol for 32 hours. The extracts were filtered using Whatman filter paper No. 42.

Reagent preparation for Phytochemical Analysis :

1\% ammonia: $1 \mathrm{ml}$ of ammonia dissolved in $99 \mathrm{ml}$ of distilled water.

$1 \%$ ammonium chloride: $1 \mathrm{~g}$ of ammonium chloride was dissolved in $100 \mathrm{ml}$ distilled water.

Mayer's reagent: It is used for the detection of alkaloids.

Solution (a) $1.36 \mathrm{~g}$ of mercuric chloride is dissolved in $60 \mathrm{ml}$ of distilled water.

(b) $5 \mathrm{~g}$ of potassium iodide is dissolved in $20 \mathrm{ml}$ of distilled water. 
Solution (a) and ( b) are mixed and the volume was adjusted to $100 \mathrm{ml}$ with distilled water.

Wagner's reagent: It is a general reagent for the detection of alkaloids. $1.27 \mathrm{~g}$ of iodine and $2 \mathrm{~g}$ of potassium iodide was dissolve in $5 \mathrm{ml}$ of water and the volume was made $100 \mathrm{ml}$ with distilled water.

Fehling's solution: It is used for the detection of reducing sugars. $34.66 \mathrm{~g}$ of copper sulphate is dissolved in distilled water and the volume was made to $500 \mathrm{ml}$ (Solution-a). 173g of potassium sodium tartrate and $50 \mathrm{~g}$ of sodium hydroxide in $\mathrm{D} / \mathrm{W}$ was dissolved and volume was made up to $500 \mathrm{ml}$ (solution -b). The two solutions were mixed in equal volume for prior use.

Ferric Chloride (alcoholic): A 5\% w/v solution of ferric chloride in $90 \%$ alcohol is used for the detection of phenols.

Lead acetate: A 25\% basic lead acetate solution is used for the detection of flavonoid.

Tests for phytochemical Screening:

Test for Sterols: Two tests Salkowski test and Liebermann-Burchard test were performed.

Test gave a positive result hence confirms the presence of Sterols.

Salkowski test: In $2 \mathrm{ml}$ of plant extract, $2 \mathrm{ml}$ of chloroform and $2 \mathrm{ml}$ of concentrated $\mathrm{H}_{2} \mathrm{SO}_{4}$ was added and shaken well. Chloroform layer appeared red and acid layer greenish yellow fluorescent.This confirms the presence of sterols.

Liebermann-Burchard Test: $2 \mathrm{ml}$ of methanolic plant extract was mixed with chloroform. 1-2 $\mathrm{ml}$ acetic anhydride and 2 drops of concentrated $\mathrm{H}_{2} \mathrm{SO}_{4}$ from the side of the test tube was added in the mixture. First red, then blue and finally green colour indicates the presence of sterols.

\section{Test for Terpenoids:}

Salkowski test gave a positive result hence confirms the presence of Terpenoids .

Salkowski test:The extract was mixed with $2 \mathrm{ml}$ of chloroform and concentrated $\mathrm{H}_{2} \mathrm{SO}_{4}(3 \mathrm{ml})$ is carefully added to form a layer. A reddish brown colouration of the interface is formed to show positive result of the presence of terpenoids.

\section{Test for Alkaloids:}

Mayer's reagent \& Wagner's reagent confirmed the presence of Alkaloids in the extract.

The Methanolic plant extract was warmed with $2 \% \mathrm{H}_{2} \mathrm{SO}_{4}$ for two minutes. It is filtered and few drops of reagents were added separately.

a. Mayer's reagent-A creamy- white colored precipitation appeared giving a positive result.

b.Wagner's reagent-A reddish-brown precipitat appeared which also confirms the presence of alkaloids in the extract.

\section{Test for carbohydrates:}

Molisch test and Fehling's test confirmed the presence of carbohydrate.

Molisch test: Treat extract with few drops of alcoholic alpha-naphthol. Add $0.2 \mathrm{ml}$ of conc sulphuric acid slowly along the sides of test tube, purple to violet colour ring appears at the junction.

Fehling's Test: Fehling A and Fehling B reagents were mixed and few drops of extract is added and boiled. A brick red coloured precipitate of cuprous oxide forms, hence cofirming the presence of carbohydrates.

\section{Test for Flavonoids:}

Ammonium Test and Aluminum Chloride Test did not confirmed the presence of flavonoids in the methanolic plant extract.

A small quantity of the extract is heated with $10 \mathrm{ml}$ of ethyl acetate in boiling water for 3 minutes. The mixture is filtered and the filtrates are used for the following test.

$\boldsymbol{A}$.Ammonium Test :The filtrate was shaken with $1 \mathrm{ml}$ of dilute ammonia solution (1\%). The layers were allowed to separate. A yellow colouration was not observed at ammonia layer which indicates the absence of the flavonoid from the plant extract.

B.Aluminum Chloride Test:The filtrates were shaken with $1 \mathrm{ml}$ of $1 \%$ aluminum chloride solution and observed for light yellow color,which did not appeared indicating the absence of flavonoids. The light yellow colour indicates the presence of flavonoid and when dilute $\mathrm{NaOH}$ and $\mathrm{HCl}$ is added the yellow solution turns colorless. 


\section{Test for Tannins:}

Ferric Chloride Test and Lead Sub Acetate Test confirmed the presence of Tannins in the plant extract.

A small quantity of the extract is boiled with $5 \mathrm{ml}$ of $45 \%$ solution of ethanol for 5 minutes. Each of the mixture is cooled and filtered. The different filtrates were used for the following test:

a.Ferric Chloride Test: $1 \mathrm{ml}$ each of filtrate is diluted with distilled water and two drops of ferric chloride is added. A transient greenish to black color indicated the presence of Tannins.

b. Lead Sub Acetate Test: $1 \mathrm{ml}$ of the different filtrate was added with three drops of lead sub acetate solution. A creamy gelatinous precipitation, indicates positive test for Tannins.

\section{Test for Phenols:}

Phenols were absent in the methanolic plant extract.

Ellagic Acid Test:The test solution was treated with few drops of 5\% (w/v) glacial acetic acid and 5\% (w/v) $\mathrm{NaNO}_{2}$ solution. The solution did not turned muddy nor Niger brown precipitate occured. Hence, the presence of phenols were not confirmed.

\section{Test for Glycosides:}

Keller-Kiliani Test and Concentrate $\mathrm{H}_{2} \mathrm{SO}_{4}$ Test confirmed the presence of Glycosides in the methanolic plant extract.

Keller-Kiliani Test: In $2 \mathrm{ml}$ plant extract, glacial acetic acid, one drop of $5 \% \mathrm{FeCl}_{3}$ and conc. $\mathrm{H}_{2} \mathrm{SO}_{4}$ were added. Reddish brown color appears at junction of the two liquid layers and upper layer appears bluish green, confirming the presence of glycosides.

Concentrate $\mathrm{H}_{2} \mathrm{SO}_{4}$ Test: In $5 \mathrm{ml}$ plant extract, $2 \mathrm{ml}$ glacial acetic acid, one drop of $5 \% \mathrm{FeCl} 3$ and conc. $\mathrm{H}_{2} \mathrm{SO}_{4}$ were added. Brown ring appears, indicating the presence of glycosides.

Test for Saponin: Foam test and haemolytic test were conducted which gave a negative result.

Foam Test: The extract was diluted with $20 \mathrm{ml}$ of distilled water and it was shaken in a graduated cylinder for 15 minutes. A layer of foam was not formed which indicated the absence of Saponin.

Haemolysis Tests: - Add leaves extract to one drop of blood placed on a glass slide. Haemolytic zone did not appeared. The test confirms that Saponin is absent in the extract.

\section{Results:}

In our study we found that the Methanolic Extract of Clerodendron infortunatum possess Sterols, Terpenoids, Alkaloids, Carbohydrates, Tannins and Glycoside, (Table 1) whereas, Flavonoids, Phenols and Saponins were absent.

TABLE : Qualitative Analysis Of The Phytochemical Components Of The Clerodendron infortunatum.

\begin{tabular}{|c|l|c|}
\hline S.no. & Phytochemical components & Result \\
\hline 1. & Sterols & ++ \\
\hline 2. & Terpenoids & ++ \\
\hline 3. & Alkaloids & ++ \\
\hline 4. & carbohydrates & - \\
\hline 5. & Flavonoids & + \\
\hline 6. & Tannins & + \\
\hline 7. & Phenols & \\
\hline 8. & Glycosides & + \\
\hline 9. & Saponins & \\
\hline
\end{tabular}

$(++)$ Strongly Present, (+)Weakly Present, (-) Absent.

\section{Conclusion:}

Secondary metabolite studies have shown that the Carbohydrates, Flavonoids, Alkaloids, Tannins, Steroids, Phenol are of great importance in the field of drug research. These classes, Alkaloids, Saponin, Tannins, Flavonoids are known to have activity against pathogens and therefore aid the antimicrobial activities of medicinal plants (Ghosh et al., 2010). In our preliminary phytochemical screening, we found that the the Methanolic Extract of Clerodendron infortunatum possess sterols, terpenoids, Alkaloids, carbohydrates, glycoside, and tannins. This suggests that leaves of Clerodendrum viscosum may possess antiinflammatory, analgesic, antidiarrhoeal, antimicrobial, antioxidant, immunomodulatory, anthelmintic, antitumour and insecticidal activities. However further studies are required in this direction for its comprehensive analysis including quantitative / semi quantitative analysis, which characterize its chemical structure and assess its biological activities. 


\section{Acknowledgement:}

The authors are grateful to the UGC for providing fund for minor project \& the Management of Ganga Devi Mahila Mahavidyalya, Kankarbagh, for providing research facilities to this study.

\section{References:}

[1]. Haines, H.H.,1925 The Botany Of Bihar and Orissa. Vol. II Bishen Singh and Mahendra Pal Signh, Dehradun India.

[2]. Shashtri, V.D., 1977 Bhavprakash Nighantu Motilal Banarsidas, New Delhi.

[3]. Tonthubthimthong P, Chuaprasert S, Douglas P, Luewisuttichat W (2001) Supercritical CO2 extraction of nimbin from neem seeds an experimental study. Journal of Food Engineering. 47: 289-293.

[4]. Fransworth, N.R. Biological And Phytochemical Screening Of Plants, Journal Of Pkarmaceutical Science.1996; Pp 55,225-227.

[5]. Wong SK, LimYY, Chan EWC (2009) Antioxidant properties of Hibiscus species variation, altitudinal change costal influence and floral colour change. Journal of Tropical Forest Science, 21: 307-315.

[6]. Nair R, KalariyaT, SumitraC, ( 2005). Antibacterial activity of some selected Indian medicinal flora.. Turkey Journal of Biology, 29: 41-47

[7]. Khan M, Wassilew SW ( 1987) Natural pesticides from the neem tree and other tropical plants. (Eds) Schmutterer H and Asher KRS, Germany: Digitalverlag GmbH, 645-650.

[8]. Kumar A, Ilavarasan R, Jayachandran T, Deecaraman M, Kumar MR, Aravindan P, Padmanabhan N, KrishanMRV(2008b) Anti inflammatory activity of Syzigium cumini seed. African Journal of Biotechnology, 7 (8): 941-943.

[9]. Jagetia G.C.,Baliga,M.S.,Venkatesh,P., (2005) Influence of seed extracts of S. cumini on mice exposed to different doses of $\gamma$ radiation. Journal of Radiation Research. 46 (1): 59-65.

[10]. Extract of Syzygium Cumini (Jamun) on Mice Exposed to Different Doses of $\gamma$-radiation. J Radiat Res (2005) 46 (1): 59-65. doi:10.1269/jrr.46.59.

[11]. Ghosh P, Mandal A, Chakraborty P, Rasul MG, Chakraborty M and SahaA (2010) Triterpenoids from Psidium guava with Biocidal Activity. Indian Journal of Pharmaceutical Science, 72 (4): 504-507. 